\title{
Impact of Selected Macro Economic Variables on Foreign Direct Investment in Kenya
}

\author{
Margaret Naliaka Kwoba, Patrick Kibati \\ Department of Entrepreneurship, Technology, Leadership and Management, Jomo Kenyatta University of Agriculture and Technology, \\ Nakuru, Kenya
}

Email address:

margaretkwoba@gmail.com (M. N. Kwoba), kibatip@yahoo.com (P. Kibati)

\section{To cite this article:}

Margaret Naliaka Kwoba, Patrick Kibati. Impact of Selected Macro Economic Variables on Foreign Direct Investment in Kenya. International Journal of Economics, Finance and Management Sciences. Vol. 4, No. 3, 2016, pp. 107-116.

doi: $10.11648 /$ j.ijefm.20160403.13

Received: April 6, 2016; Accepted: April 16, 2016; Published: April 28, 2016

\begin{abstract}
Foreign direct investment is one of the major sources of external finance for developing countries like Kenya that have a limited amount of capital. Foreign flows into the country so far have been increasing as compared to the previous year's revealing Kenya potential as a business hub for multinational companies to invest in. However, the inability to retain FDI flows into the country has become a major problem and understanding the factors driving FDI inflows into a country and their impact on a country's economic development is of importance. The main objective was to find out the impact of exchange rate, GDP and inflation on FDI in Kenya. Foreign direct investment as a percentage of GDP was the dependent variable while the independent variables were exchange rate, GDP and Inflation rate. The study examined data for 10 years from $2005-2014$ for Kenya. To find out the perception of people towards FDI in Kenya primary data was collected from a sample of 271 people. A linear regression analysis was used to determine the relationship between exchange rate, GDP, inflation rate and FDI inflows. Exchange rate, GDP and Inflation rate were found to have a negative insignificant effect on FDI inflows. The study also found out that people in Kenya perceive FDIs as market seeking investments that is they will invest if there is availability of market for the goods and services produced. The study recommends that Policies in relation to formation of regional treaties between Kenya and neighboring countries with an aim of encouraging foreign investment should be made. Security should also be maintained within and around the country and political stability is also crucial in attracting and retaining FDIs. In addition the government should increase its fight against corruption in Kenya so as to increase the foreign investor's confidence in investing in our country.
\end{abstract}

Keywords: Exchange Rate, Foreign Direct Investment, Gross Domestic Product, Inflation Rate

\section{Introduction}

\subsection{Background}

Foreign direct investment (FDI) is an investment involving acquiring or creation of assets that is undertaken by foreigners or a joint venture with local governments with the main aim of creating a long-term relationship. Moreover, this may lead to a lasting interest and control by a resident entity in one economy(foreign direct investor or parent enterprise) in an enterprise resident in an economy other than that of the foreign direct investor(FDI enterprise or affiliate enterprise or foreign affiliate). Aremu (2005) highlights the growing interest in FDI being driven by the perceived opportunities that can be derived from utilization of foreign capital injection into the economy to add to domestic savings and promote economic growth in most developing economies. Policy makers in developing countries and emerging market economies (EMEs) view FDIs as a tool to finance development increase the productivity of a country and import new technologies. FDI inflow stability creates a barrier against reversals in Portfolio inflows during crisis periods such as one experienced in 2009 (Arbatili, 2011). Over the ears, FDI has become one of the main sources of capital flow linking various country economies hence becoming a major catalyst towards the growth of economies 
in developing countries such as Kenya (Leitao, 2012; Mallampally \& Sauvant, 1999; OECD, 2002). FDI is one of the most important links between countries that are developing and industrial countries as it forms an important channel for global integration and transfer of technology between countries (Muthoga, 2003) and has been known to provide several benefits to the economies of countries around the world. For instance, it not only serves as a source of development finance for these countries' but also increases the level of technical progress in the host country and in turn plays an important role in the process of economic development. In addition, FDI improves managerial knowledge and skills, reduces unemployment as well as increases efficiency in productivity. It also provides a wide array of goods and services to the economy. Furthermore, FDI promotes exports and hence can have a positive impact on a country's balance of payment (Enu, Havi and Obeng, 2013).

According to UNCTAD (2015), FDI flows have accounted for more than forty per cent of external development finance to developing and transition economies. This has seen FDI flows to developed countries drop by twenty eight per cent while flows to developing countries increase by two per cent in 2014(OECD, 2014). The global foreign direct investment (FDI) inflows in the year 2014 declined by eight percent owing to the fragility of the global economy, uncertainty associated with policies and geopolitical risks. Divestment in the United States lowered FDI flows globally (UNCTAD, 2015). According to UNCTAD in its 2014 world investment report the rise in FDI inflows in Africa was mainly driven by international and regional market seeking flows and Infrastructure Investments. Omankhanlen (2011) highlights the relationship between host countries and parent countries in an international system as the most powerful obstacle to the development of developing countries. For the east African countries to attract more FDI it is recommended that harmonizing of investment policies, development of infrastructure, political stability and enhancing of Investment Promotion Activities by the Investment Authority will lead to economic and social development (Mahiti, 2012).

In recent times Kenya's FDI inflows has outpaced those of other east African countries that have previously attracted more inflows mainly directed towards the resources extractive sector(UNCTAD,2015).This upsurge in FDI according to the world bank (2015) has been mainly attributed to not only the interest by the Chinese in the construction industry but also the move to manufacturing and communications by the setting up of Xinhua News and the China Central Television African headquarters in Nairobi (Ocharo, 2014).Abala (2014) describes FDI in Kenya as mainly market seeking which requires growing GDPs, political stability, good infrastructure, availability of market as well as low corruption levels which is significant for economic growth as it provides the required capital, leads to increase in competition in the host countries and local firms are able to become more industrious through the adoption of more efficient technology. Kenya has continued to be one of the preferred business hubs for oil and gas exploration, industrial production and transport in the sub-region (UNCTAD, 1998). IMF (2014), has highlighted the extensive institutional reforms and prudent macroeconomic policy in Kenya has created a market-friendly environment for FDI. An important question for policy makers is therefore, which factors are important in driving FDI inflows to in a country and what effect do they have on FDIs inflows.

\subsection{Objectives}

\subsubsection{General Objective}

The general objective of the study was to analyse the impact of exchange rate, Gross domestic product and inflation rate on foreign direct investment in Kenya.

\subsubsection{Specific Objectives}

i. To determine the impact of exchange rate on foreign direct investment in Kenya.

ii. To establish the relationship between gross domestic product and foreign direct investment in Kenya

iii. To examine the impact of inflation rate on foreign direct investment in Kenya

iv. To find out the perception of people on foreign direct investment in Kenya.

\section{Literature Review}

\subsection{Theoretical Review}

From a macroeconomic point of view, FDI is a particular form of capital flows from the countries of origin to the host countries where the capital flows are found in the balance of payments. According to Lipsey (2001) the macroeconomic theories explain what motivates the investors to investment in foreign countries Woldemeskel (2008) further identified the macro-level factors that affects the host country's FDI flows as market size, economic growth rate, GDP, infrastructure, natural resources, political situation, Interest rates, Inflation rates, unemployment rates, exchange rates etc.

\subsubsection{Capital Arbitrage Theory}

Beghum N, Sannassee R V et al (2009) identified the capital market theory developed by Hymer in the $1960-1969$ which states that FDI is determined by interest rates. Capital market theory laid down three reasons which attract FDI to the less developed countries. The undervalued exchange rate has been identified as one of the reasons that attract FDI. This is because it allows lower production costs in the host countries, the second reason is that since there is no organized securities that exist, long term investments in less developed countries will often be FDI rather than purchase of securities, the third reason is that since there is limited knowledge about host countries securities that is why it favours FDI which allows control of host country assets.

This theory further states that FDI flows from countries where the profit is low to countries where profit will be high. This means that capital the theory states that. Direct investment flows from countries where profitability is low to 
countries where profitability is high. It means therefore that capital is moves both nationwide and internationally. Moreover there are implications and countries with more capital should export and the country with less capital should import. A linkage between long-term interest rate and return on capital should go in the same direction...Most investors will go to countries that will earn them a higher return. But due to globalization, capital markets have grown across the world and it is argued that such theory is not reliable in explaining cross border investment of multinational companies. When imperfections in the market such as uncertainty or business risks are included in the model, the movement of resources internationally is no longer reactive to interest rates (Beghum N, Sannassee R V et al, 2009).

\subsubsection{Dynamic Macroeconomic FDI Theory}

Another macroeconomic theory identified in the study carried out by Beghum \& Sannassee et al (2009) is the dynamic macroeconomic FDI theory. According to this theory, the timing of investments depends on the changes in the macroeconomic environment as stated by SanjayaLall. The macroeconomic environment consists of gross domestic product, domestic investment, the real exchange rate, productivity and openness which are some of the factors that affect the FDIs flows in a country. These theory further states that FDIs are a long term function for multinational companies and period of time plays an important function.

The timing of investment will depend on the macroeconomic environment that is the political environment, the inflation rate, exchange rate, interest rate, market size, government policies etc at that particular period in the host country as well as its degree of openness and rate of economic development as well as Risk perceptions lie as a determinant. It is important for a foreign investor to analyse an understand the investment environment of a country and the risk associated with the investment environment as the macro environment is country specific and the effect of one variable will not be the same as in another same as in another economic environment.

\subsubsection{Economic Geography Theory}

Yarbrough \& Yarbrough (2002), discussed economic geography theory which focuses on individual countries and explains why international successful industries emerge in particular countries. They assume that the decision of a Transnational Corporation (TNC) on which province to locate investment depends on a set of characteristics of the host province affecting firm's revenue or costs such as factor $\mathrm{s}$ as the natural resources, the demand for the products and services, income per capita, availability of skilled labour, infrastructure, policy actions by the government among others. Aiello et al. (2009) argue that other things being equal, a change in infrastructure expenditure influences the cost faced by the firm in adjusting its current capital stock to the target level. They argue that this is a reasonable assumption, given that the adjustment costs depend not only on the firm's internal characteristics, but also on external factors, such as the provision of public infrastructure.

\subsection{Empirical Review}

\subsubsection{Foreign Direct Investment}

The increase in FDI has been singled out as one of the most important factor for reducing poverty (Mwega and Ngugi, 2006). Developing countries such as Kenya are mostly interested in FDI a source of capital because FDI involves investments that are long term to the host country and contributes a lot to the GDP capital formation.FDI has been identified to contribute considerably to the economic development of countries. Governments of various host countries are using policy incentives such as tax allowances and grants in aid so as to attract and retain FDI into their economies due to the benefits linked to FDI inflows. Numerous papers have suggested that foreign companies are able to positively influence the levels of production and growth rates in the industries they enter and to also prove the skills, increase employment and increased innovation (Africa trade policy center, 2005; Abala, 2014; Gathaiya, Kinyua et al, 2014, UNCTAD, 2005). However, it's also argued that FDI might lower or replace domestic assets and investment, transfer low level or unsuitable technologies for the host countries and can even thwart the development of local firms thus limiting growth. By focusing only on local labour that is cheap and raw materials, foreign firms may end up not being helpful in developing the host country's dynamic comparative advantages (UNCTAD, 2005).

Nevertheless, the negative repercussions of FDI can be controlled with proper trade and labour regulation (Rose and Mwega, 2006; Kinuthia 2010). There are three main types of FDIs. The market-seeking FDI usually serve local and regional markets and involves the reproduction facilities in the host economies. A variant of this type of FDI is also known as Tariff jumping or export-substitution FDI and it is driven largely by the size of the market and market growth of the host country. Due to market and income considerations FDIs in small and poor countries are not likely to be of the market seeking type (Lim, 2001)

\subsubsection{Exchange Rate and Foreign Direct Investment}

One of the many influences on foreign direct investment activity is the behavior of exchange rates. This is because the exchange rates can influence equally the total amount of foreign direct investment that takes place as well as the allocation of this investment spending across a range of countries. Oude (2013) highlights that the exchange rate fluctuations are mainly caused by changes in the demand and supply of the money in the FOREX market. When imports surpass the exports, the exchange rate will appreciate and rise in value. However if the exports exceeds the imports, then the exchange rate falls in value and depreciates. In the longrun, changes in the demand and supply of money depend on changes in the value of goods imported and exported as well as long-term capital flows such as foreign direct investments (FDI).

The exchange rate is an important determinant of international trade in consideration to export earnings generated. This concept has received a lot of attention in the 
context of global imbalances in international trade. Research linked to exchange rate management still remains a topic of interest to economists, especially in countries that are developing, despite a relatively massive body of literature in the area. The exchange rate links the domestic market with the world markets for goods and assets and also a determinant of the level of competitiveness of a country's exchange rate with the rest of the world. Moreover, there is no simple answer as to what will determine the stability of exchange rate. Estimating equilibrium exchange rates and the degree of exchange rate fluctuations remains one of the most difficult observed problems in open economy macroeconomics. According to Chang and David (2005), the fundamental difficulty is that the equilibrium value of the exchange rate is not observable. An exchange rate is said to be undervalued when it reduces more than its equilibrium, and overvalued when it increases more than its equilibrium. The issue is, unless the equilibrium is explicitly specified, the concept of exchange rate fluctuations remains biased.

A high exchange rate level lowers the receipts that exporters receive thereby decreasing export earnings. On the other hand, a low exchange rate level raises receipts that exporters receive thereby improving export earnings. A fluctuation in the exchange rate impacts directly either positively or negatively on export earnings. Exchange rate fluctuations might impact negatively on exporters and trend economic growth by discouraging firms from undertaking investment, innovation and trade. It may also discourage firms from entering the market for export. Large fluctuations in foreign exchange rate force changes in costs on the economy. This could eternally shift resources to non-tradable sectors if firms are put off from export markets due to high foreign exchange rate fluctuations (Kiptui, 2007). If exchange rate movements are not fully predictable, an increase in exchange rate fluctuations may lead risk-averse agents to reduce their international trading activities.. On the other hand Chakrabarti (2001) highlights that a stable rate of exchange will create a positive environment for FDI while a highly unstable exchange rate makes it difficult to predict the costs and profits on FDI.

The $\mathrm{CBK}^{\mathrm{ee}} \mathrm{s}$ main purpose is to plan and implement policy to achieve stability in overall price levels and this includes the exchange rate. In order to achieve price stability, the CBK uses a combination of indirect monetary policy tools and instruments such as open market operations and minimum requirements stipulated by law (CBK, 2013). The current rapid depreciation of the Kenya shilling has highlighted key fundamental flaws in the administration of country's economy, it brought to core questions on the sustainability of the current economic model. The trade deficit is blamed for depreciation of the Shilling against the dollar and other major currencies. The central bank and treasury have put in motion various measures that should see the shilling stabilize against the dollar. Currently the country is highly importing and too little is being exported which is the main reason as to why Kenya's economy is increasingly imbalanced. This makes the economy exposed to shocks. The gap between imported goods and services and exported goods and services has to be financed by the financial inflows other than earnings from selling goods and services outside the country. In 2011, imports have reduced because of high prices of oil and food, while exports stagnated.

A deteriorating Shilling is not necessarily bad for Kenya's economy as it can help to rebalance Kenya's economy in the medium term, by making goods and services bought outside the country more expensive and goods and services sold outside the country more competitive in the countries where goods are sold and bought, thus adding to export earnings. Unfortunately, in Kenya, the increase in consumer prices has been consuming away some of the benefits that it would get from a lower rate of exchange, thus creating additional strain on the Shilling. If local and international investors, know their money will lose its value in Kenya very quickly which happens when inflation rate goes up they will move it to countries where their money value will be high over the medium-term. If policy makers are not vigilant, Kenya could end-up in a vicious cycle where prices for food and fuel are high leading to higher inflation, which in turn weakens the exchange rate, which raises the cost of buying goods and services from other countries, which further increases inflation which would be a bad effect for Kenya (The World Bank, 2015)

\subsubsection{Gross Domestic Product and Foreign Direct Investment}

The Performance of the host country in terms of its GDP is an important factor that boosts investor confidence and the government should find ways to promote local production. Many local companies are currently operating below capacity because of the decaying state of machines and equipment and therefore the government can intervene to boost production of those companies. The government can also help to promote local production through research and gathering of essential information that can affect the performance of industries. This can also help to reduce research and information cost to local companies (Chingarande, A., Karambakuwa, T. Et al, 2011).

Studies carried out by M. Dritsaki, C. Dritsaki and A. Adamopoulos (2004) on the analysis of how FDI, export and economic growth relate to each other in Greece for the years between of 1960-2002 have shown that the there is existence of a long run equilibrium relationship among the variables analyzed using the co integration test while Granger causality results showed a causal relationship existed on those variables the other hand Miankhel, Thangavelu and Kalirajan (2009) did the causality test between FDI, export and GDP represented by economic growth for Pakistan, India, Malaysia, Mexico, Thailand and chile where their findings were different for all the six nations. Their findings specifically reveal that economic growth attracts FDI in India in the long run that while GDP influence export in Pakistan. The study shows that Thailand had a bidirectional relationship between FDI and GDP implying that FDI leads to GDP and hence GDP attracts FDI. Dasgupta (2007) 
examined the long run impact of export, imports and FDI inflows on the outflows of FDI in India and his empirical results suggested the presence of Unidirectional causality running from the export and import to FDI out flows. The results found no causality existed from FDI inflows to the outflows.

According to the study by Syed (2012) on the investigation of the causal linkage between trade FDI and economic growth of Bangladesh between 1973 to 2008.In his study he found that in the co integration test there was a long run relationship on the variables being analyzed while he also found that economic growth influences both FDI and export and that there was the existence of a unidirectional causal relation between FDI and export which runs from export to FDI. Shimul and Siddiqua (2009) found no existence of the linkage of FDI and GDP for Bangladesh for a period between 1973-2007 while Mohammad (2009) using the methodology of Toda and Yamamoto examined the causal relationship between FDI and economic growth for a period between 1970 to 2005 and found no strong evidence of bi-directional causality between the two variables hence he suggested that FDI has an indirect effect on economic growth in Malaysia. Chow P. (1987) carried out an empirical investigation on the causal relationships between export growth and industrial development in eight newly industrializing countries found out that there is a strong bidirectional causality relationships between the export growth and industrial development which support the export led growth strategy in the sense that with the export expansion there will be the national income growth of the country.

Chakraborty and Basu (2002) Investigated on the relationship between economic growth and foreign direct investment (FDI) in India by employing the co integration and error correction model method and found out that there is unidirectional relationship with causation running from GDP to FDI and not otherwise. In his study Athukorala (2003) on The Impact of FDI on Economic Growth in Sri Lanka showed that FDI inflows did not exert an independent influence on economic growth and the direction of causation was from GDP growth to FDI rather than FDI to GDP growth. Njeru N. (2013) identified several studies that were carried out in Nigeria on the function of foreign direct investment (FDI) in the Nigerian economy. Such studies include Langley who argued that FDI has both benefits and costs in the perspective of Nigeria's growth of the economy. He said while FDI could engineer or speed up gross domestic product growth (GDP) through the combination of new techniques and managerial efficiency, Langelywarns that it could also worsen the balance of payments position (Akinlo, 2004). Oseghaleand Amenkhienan examined the relationship between oil export, foreign borrowing and foreign direct investment in Nigeria on one hand and economic development on the other hand, and the impact of these on the performance of different sectors between 1960 and 1984 . They concluded that foreign borrowing and FDI has a negatively impact on the over-all GDP but a positive impact on three principal sectors i.e. manufacturing, transport, communication and finance and insurance. Chete (1998) and Anyanwu (1998) separately examined the determinants of FDI in Nigeria using error correction model. Chete concluded that the growth of the economy measured by GDP growth rate has positive effect on FDI but became significant only at the third lag (Njeru, N. 2013).

\subsubsection{Inflation Rate and Foreign Direct Investment}

Akinboade (2006), highlighted that low inflation is taken to be a sign of internal economic stability in the host country. Any form of instability introduces a form of uncertainty that distorts investor perception of the future profitability in the country. Chingarande \& Karambakuwa et al (2011) supported the statement that a stable economy attracts more FDI thus a low inflation environment is desired in countries that promote FDI as a source of capital flow. Therefore the study expects a negative relationship in the regression analysis. Chingarande \& Karambakuwa et al (2011), noted that Inflation has a negative impact on investment only if it riches a certain threshold. Usually a certain level of inflation, particularly a single digit, is desirable to stimulate investment in an economy. Negative inflation rates will discourage investors due to lower rate of return in profits and hence the government should control and regulate inflation rate around levels that stimulate investment. Udoh and Egwaikhide (2008) carried out a study to link up inflation and FDI where they used annual time series data covering the period 1970 to 2005 to examine the effect of exchange volatility and inflation uncertainty on FDI in Nigeria. They employed the GARCH model to estimate inflation uncertainty and exchange rate volatility. The findings indicated that inflation has a negative effect on FDI and it is statistically significant.

Furthermore Ade et al (2011), explored the link between corruption, FDI and growth in Nigeria using annual time series data over the period 1990 to 2009. The Johansen approach to co integration lends support to the results of Udoh and Egwaikhide (2008) that low and stable inflation attracts FDI inflows into developing countries to spur growth. The granger causality test however, proves the absence of any directional causality between inflation and FDI. Omankhanlen (2011) carried out a research on the effect of inflation and foreign exchange rates on FDI in Nigeria, and the findings showed that whereas inflation rate did not have major effect on the inflow of FDI into the Nigerian economy, foreign exchange rate had great effect on the inflow of FDI into the Nigerian economy within the same period (1980-2009) on the other hand though Nigeria's inflation rate did not have major effect on FDIs inflow, inflation rates in other countries may greatly affect the exchange rate making it rise discouraging foreign direct investment.

According to Sajib et al. (2012) where they analysed the role of FDI and trade on the growth in Pakistan by employing the Simple Least Square Method using annual time series data from 1990 to 2008, results indicated a positive and not statistically significant relationship between inflation and FDI. Shumaila et al. (2012) supported Sajib et al. (2012) 
when further studies were carried out on the impact of capital inflows on domestic inflation in Pakistan over the period 1980 to 2010 using co integration test and error correction model. Anna (2012) and Singhania (2011) conquer that Inflation rate has an effect on capital preservation of FDI and further conclude that Higher or lower inflation can affect profitability as high or low prices can lead to increase in cost or low profits and therefore stable inflation rate is desirable for FDI. However, their findings are in disagreement the work of Djokoto (2012) who investigated the effect of investment promotion on foreign direct investment inflow in Ghana for the period 1970 to 2009 where he discovered a negative relationship between inflation and FDI. The differing result was due to the fact that Djokoto used co integration technique and treats inflation as a control

\subsection{Conceptual Framework}

Explanatory variable

Affects

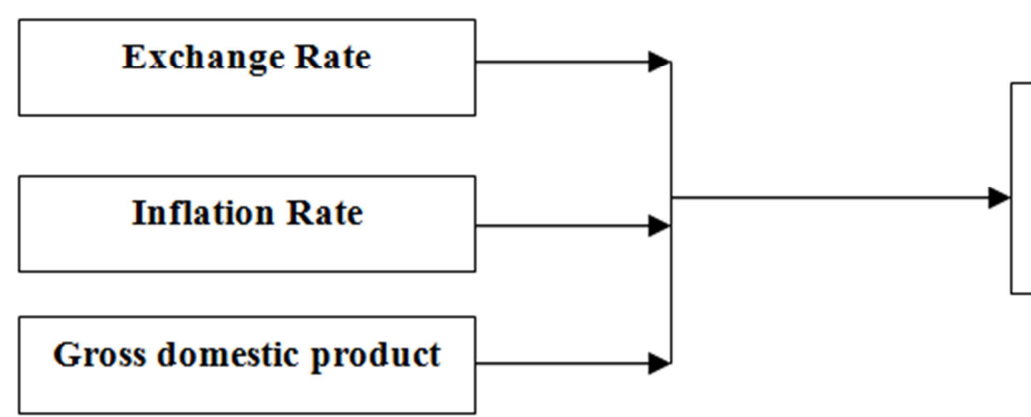

Dependent Variable

Figure 1. Conceptual framework.

\section{Model Specification}

From economic theory, inflation and exchange rate have been known to affect the inflow of Foreign Direct Investment (FDI) in any country. The model of this study is as specified below

$$
F D I=f(E X R, G D P, I N F L)
$$

FDI $=$ inflow of Foreign Direct Investment as a percentage of GDP

EXR. $=$ Annual Exchange rate

GDP $=$ Gross domestic product (annual percentage)

INFL $=$ Inflation rate measured by the annual $\%$ change in consumer price index

Linearizing function (1) above we get the statistical regression model.

$$
F D I_{t}=\beta_{0}+\beta_{1} E X R_{t}+\beta_{2} G D P_{t}+\beta_{3} I N F L_{t}+\varepsilon_{t}
$$

Where

$\beta_{0}=$ the intercept for equation

$\beta_{1}=$ the parameter estimate of EXR.

$\beta_{2}=$ the parameter estimate of GDP

$\beta_{3}=$ the parameter estimate of INFL.

$\mathcal{E}_{i t}=$ the random variable or error term. variable.

Andinuur (2013) studied inflation, foreign direct investment and economic growth in Ghana where he concluded that GDP growth relate positively with FDI and negatively with inflation both in the long run and short run where as the relationship between inflation and foreign direct investment is positively. Furthermore, a unidirectional causal links were found from GDP and FDI to inflation. There was no directional causal relationship inflation to GDP and FDI and finally, a unidirectional causality was discovered running from GDP to inflation. All causal links were statistically significant. He also suggests that to deal with the problem of inflation, policies should be geared towards addressing the real economic factors that deter GDP growth in Ghana

\section{Foreign Direct \\ Investment}

\subsection{Data Collection Procedure}

The study used both primary and secondary data. Secondary data was obtained from the Central bank of Kenya, the Kenya National bureau of statistics, International Monetary Fund (World Economic Outlook Database) and the World Bank (WDI) while primary data was collected using a questionnaire. A data collection checklist was used for secondary data collection process while Excel spreadsheet was used in the data editing and coding.

\subsection{Data and Methodology}

The study set out to analyze the impact of selected macroeconomic variables on foreign direct investment for the period 2005-2014 in the Kenya. Time series data was used, data analysis using SPSS software was employed to find out the relationship between the variables. The data used was obtained from the World development Indicators database, Central Bank of Kenya and Kenya national bureau of statistics. A Durbin Watson test was used to test for Autocorrelation and correlation matrix used to test for multicolinearity. To find out the perception of people in Kenya towards FDI primary data was collected from a sample of 271 . 


\section{Empirical Analysis and Presentation of Results}

\subsection{Descriptive Analysis}

Descriptive analysis involves finding the average values of the variables (mean), the medians of the series, the maximum and the minimum values in the series sample, measure of spread of the variables (standard deviation), Table 1 below is thus a summary for the descriptive statistics.

Table 1. Descriptive statistics.

\begin{tabular}{lllll}
\hline & FDI & EXCH & GDP & INF \\
\hline Mean & 0.65 & 78.86 & 5.28 & 8,5 \\
Minimum & 0.19 & 67.21 & 0.23 & 4.08 \\
Maximum & 2.281 & 88.72 & 8.40 & 15.10 \\
Std. Dev. & 0.71 & 7.83 & 2.23 & 3.87 \\
Observations & 10 & 10 & 10 & 10 \\
\hline
\end{tabular}

Source: SPSS output for Research data, 2016

Note: GDP $=$ Gross Domestic Product; $\mathrm{EXCH}=$ Annual Exchange rate; FDI

$=$ Foreign direct investment net inflows as a $\%$ of GDP; INF $=$ Annual Inflation rate

According to table 1, between the period 2005 and 2014, the average net inflows for FDI were 0.65 for Kenya, the average exchange rate 78.86 , the average GDP was 5.28 and the average inflation rate was 8.5. The lowest FDI net inflows in Kenya 0.16 in 2006. This according to Nyamwange (2009), was because Kenya lost its competitiveness in attracting investment and retaining the stock of investment. The loss in Kenya's investment competitiveness was a result of many inter-connected factors such as negative view by investors about, poor infrastructure political instability, poor governance, corruption, insecurity, crime, theft, and policy instability.

\subsection{Correlation Analysis}

Correlation analysis is a measure of the degree of association between variables. Correlation Matrix depicted in the table 2 indicates a relatively low correlation between the independent variables. This implies the possibility of not having multicolinearity problems as all the correlation values between the independent variables are within the range of 0.8 to 0.8 .

Table 2. Correlation Matrix table.

\begin{tabular}{lllll}
\hline & FDI & EXCH & GDP & INF \\
\hline FDI & 1 & & & \\
EXCH & -0.133 & 1 & & \\
GDPPC & 0.259 & 0.192 & 1 & \\
INF & -0.509 & -0.0166 & -0.736 & 1 \\
\hline
\end{tabular}

Source: SPSS output for Research data, 2016

Table 2 further indicates positive correlation between FDI and GDP. In addition, the negative correlation between inflation rate and FDI is in agreement with Chingarande \& Karambakuwa et al (2011) correlation findings of the same variables. Exchange rate also depicts a negative correlation.
There was no Multicollinearity problem as the correlation values were between -0.8 and 0.8 .

\subsection{Regression Model Analysis}

The regression estimation results are summarized in table 3

Table 3. Summary results.

\begin{tabular}{ll}
\hline Model & \\
\hline Constant & 2.40 \\
& $(0.938)$ \\
Exchange rate & -0.004 \\
& $(-0.122)$ \\
GDP & -0.072 \\
& $(-0.417)$ \\
Inflation rate & -0.122 \\
& $(-1.257)$ \\
F statistic & 1.081 \\
DW & 2.370 \\
\hline
\end{tabular}

Source: SPSS for Research data, 2016

$t$ values for the coefficients are in brackets. DW $=$ Durbin Watson test; GDP $=$ Gross Domestic Product annual percentage; $\mathrm{EXCH}=$ Annual Exchange rate; FDI = Foreign direct investment net inflows as a percentage of GDP; $\mathrm{INF}=$ Annual Inflation rate

The empirical results in table 4.4 show that the constant term had positive coefficients while exchange rate, GDP and inflation had a negative coefficient. All the coefficients of explanatory variables are thus in line with expectations according to economic theory (Andinuur, 2013; Chingarande \& Karambakuwa et al, 2011; Bouoiyour and Rey, 2005). GDP, Exchange rate, Inflation and the constant term were statistically insignificant since their associated t-statistics was less than 2. It's also worth noting that the standard approach to testing significance of variables is also by looking whether their associated t-statistic values are greater than 2 . That is, a variable is statistically significant if its associated t-value is greater than 2 otherwise the variables is said to be statistically insignificant in explaining the changes in the dependent variable.

To summarize the results, the exchange rate, GDP and inflation rate had a negative influence on FDI. The DurbinWatson (DW) test statistic for the model also depicted the model did not suffer from autocorrelation problems, i.e. the DW was 2.37 and the F statistic was greater than one i.e. 1.081 meaning there was no presence of heteroscedasticity.

The regression model is as per equation 3 .

$$
\begin{aligned}
F D I_{t}= & 2.40-0.004 E X C H_{t}-0.072 G D P_{t}-0.122 I N F_{t}+\varepsilon_{i t} \\
& (0.938) \quad(-0.122) \quad(-0.417) \quad(-1.257)
\end{aligned}
$$

Note: The values in brackets are the t-statistics

Equation 3 derived from table 3 shows that an increase in exchange rate leads to a reduction in FDI by $0.4 \%$. This implies that exchange rate is inversely related to FDI. In addition, exchange rate was found to be insignificant. The coefficient of the GDP and INF was negative which implies that FDI reduces by $7.2 \%$ and $12.2 \%$ respectively. The 
negative relationship therefore implies that GDP, exchange rate and inflation rate are negatively related to FDI inflows in Kenya and are insignificant in determining FDI inflows in Kenya. The negative relationship between exchange rate, GDP and inflation rate on FDI may be attributed to the time period under study as during this period, the country experienced postelection violence in 2007/2008 which quickly worsened the public order and proved to be severely damaging leading to the stagnation of FDI inflows (Nabutola, 2009). This finding is also in agreement with Omankhanlen, A. E. (2011), Umeora (2013) and Udomkerdmongkol M. et al (2006) findings on the same variables.

Moreover, the global financial crisis experienced in 20072008 may have attributed to the negative relationship between GDP and FDI and is considered by economists to be the worst financial crisis ever experienced leading to the failure of many businesses. The crisis led to the current account deficit, national currency depreciation and the budget deficit further leading to uncertainty with regards to the future impacts of the crisis which was a major deterrent to investment and in turn a major driver of economic growth. The findings are in agreement with Yap Et al (2009) and
Adina et al (2012) who stated that GDP and FDI were both in decline during this period because of the global financial crisis that hit world economies with countries such as Greece and Spain still undergoing the recovery process. The effect of exchange rate, GDP and inflation rate on FDI is also country specific and may further depend on other factors such as political stability, integrity and bureaucracies in government institutions as well as other economic policies in place. Therefore, the government needs to consider reform measures such as human capital development, increasing competitiveness in the market by reducing barriers to entry and deregulation in the markets to encourage new entrants so as to promote FDI inflows in the country.

\subsection{Perception of People on Foreign Direct Investment}

This section aimed to find out the perception of people on FDIs in Kenya. Data from a sample of 271 people was collected to find out the reasons as to why foreign investors are attracted to invest directly in the country.

\subsubsection{General Information}

Table 4. Response rate.

\begin{tabular}{llllll}
\hline & & Frequency & Percent & Valid Percent & Cumulative Percent \\
\hline \multirow{3}{*}{ Valid } & Non response & 3 & 1.1 & 1.1 & 1.1 \\
& Responded & 268 & 98.9 & 98.9 & 100.0 \\
\hline
\end{tabular}

Table 4 above shows findings that emanated from the study with regards to the response rate. The researcher sampled 271 respondents to study. Majority of the respondents provided feedback with a response rate of ninety eight percent. Those that did not respond simply declined to provide feedback. Mugenda and Mugenda (2009) indicated that a response rate of $50 \%$ is adequate; a rate of $60 \%$ is good and a response rate of $70 \%$ and over is excellent.

\subsubsection{Reasons for Foreign Direct Investment in Kenya}

Table 5. Favourable investment policies.

\begin{tabular}{llllll}
\hline & Frequency & Percent & $\begin{array}{l}\text { Valid } \\
\text { Percent }\end{array}$ & $\begin{array}{l}\text { Cumulative } \\
\text { Percent }\end{array}$ \\
\hline \multirow{4}{*}{ most important } & 58 & 21.6 & 21.6 & 21.6 \\
& 2nd choice & 47 & 17.5 & 17.5 & 39.2 \\
\multirow{2}{*}{ Valid } & 3rd choice & 70 & 26.1 & 26.1 & 65.3 \\
& 4th choice & 22 & 8.2 & 8.2 & 73.5 \\
& least important & 71 & 26.5 & 26.5 & 100.0 \\
\hline & Total & 268 & 100.0 & 100.0 & \\
\hline
\end{tabular}

Table 5 ranks investment policy as one of the least important reasons why foreign investors are attracted to invest in Kenya. 71 people (26.5\%) rank investment policy as the least important reason for investing in Kenya and 58 people $(21.6 \%)$ rank favourable investment policies as one of the reasons for investment.
Table 6. Research and technological expertise.

\begin{tabular}{llllll}
\hline & Frequency & Percent & $\begin{array}{l}\text { Valid } \\
\text { Percent }\end{array}$ & $\begin{array}{l}\text { Cumulative } \\
\text { Percent }\end{array}$ \\
\hline \multirow{6}{*}{ Valid } & most important & 36 & 13.4 & 13.4 & 13.4 \\
& 2nd choice & 34 & 12.7 & 12.7 & 26.1 \\
& 3rd choice & 34 & 12.7 & 12.7 & 38.8 \\
& 4th choice & 60 & 22.4 & 22.4 & 61.2 \\
& least important & 104 & 38.8 & 38.8 & 100.0 \\
& Total & 268 & 100.0 & 100.0 & \\
\hline
\end{tabular}

The table above sows thirty six (13.4) people ranking research and technological expertise as one of the most important reason for investment while one hundred and four people (38.8\%) rank it as the least reason for investing in Kenya.

Table 7. Resources.

\begin{tabular}{llllll}
\hline & Frequency & Percent & $\begin{array}{l}\text { Valid } \\
\text { Percent }\end{array}$ & $\begin{array}{l}\text { Cumulative } \\
\text { Percent }\end{array}$ \\
\hline \multirow{6}{*}{ Valid } & most important & 59 & 22.0 & 22.0 & 22.0 \\
& 2nd choice & 96 & 35.8 & 35.8 & 57.8 \\
& 3rd choice & 58 & 21.6 & 21.6 & 79.5 \\
& 4th choice & 44 & 16.4 & 16.4 & 95.9 \\
& least important & 11 & 4.1 & 4.1 & 100.0 \\
& Total & 268 & 100.0 & 100.0 & \\
\hline
\end{tabular}

The table 7 above displays fifty nine people (22\%) rank resources as one of the most important reason for investment while eleven people (4.1\%) rank resources as one of the least important reason for investing in Kenya. 
Table 8. Availability of Market.

\begin{tabular}{lllll}
\hline & Frequency & Percent & $\begin{array}{l}\text { Valid } \\
\text { Percent }\end{array}$ & $\begin{array}{l}\text { Cumulative } \\
\text { Percent }\end{array}$ \\
\hline most important & 69 & 25.7 & 25.7 & 25.7 \\
2nd choice & 46 & 17.2 & 17.2 & 42.9 \\
3rd choice & 58 & 21.6 & 21.6 & 64.6 \\
4th choice & 84 & 31.3 & 31.3 & 95.9 \\
least important & 11 & 4.1 & 4.1 & 100.0 \\
Total & 268 & 100.0 & 100.0 & \\
\hline
\end{tabular}

The table 8 above shows sixty nine people (25.7\%) rank availability of market as one of the most important reason for investment while eleven people (4.1\%) rank marketability as one of the least important reason for investing in Kenya. Forty six people rank market as their second choice, fifty eight people rank as their third choice and eighty four people rank market as the fourth choice for investment.

Table 9. Political goodwill.

\begin{tabular}{llllll}
\hline & Frequency & Percent & $\begin{array}{l}\text { Valid } \\
\text { Percent }\end{array}$ & $\begin{array}{l}\text { Cumulative } \\
\text { Percent }\end{array}$ \\
\hline \multirow{6}{*}{ Valid } & most important & 34 & 12.7 & 12.7 & 12.7 \\
& 2nd choice & 33 & 12.3 & 12.3 & 25.0 \\
& 3rd choice & 48 & 17.9 & 17.9 & 42.9 \\
& 4th choice & 70 & 26.1 & 26.1 & 69.0 \\
& least important & 83 & 31.0 & 31.0 & 100.0 \\
& Total & 268 & 100.0 & 100.0 & \\
\hline
\end{tabular}

The table 9 above shows thirty four people (12.7\%) rank political goodwill as one of the most important reason for investment while eighty three people (31\%) rank political goodwill as one of the least important reason for investing in Kenya.

In summary, most people perceived the availability of market to be the most important reason for investment (69\%) followed by availability of resources (59\%), favourable investment policies (58\%), research and technological expertise (36\%) and lastly political good will of the country.

\section{Conclusion and Policy Recommendations}

The study set out to investigate the impact of exchange rate, gross domestic product, and inflation rate on FDI. Macroeconomic variables under study were exchange rate, GDP and inflation rate. GDP, Inflation rate and exchange rate were insignificant in determining the inflows of FDI. The findings show that GDP, Exchange rate, inflation rate is not a significant determinant of FDI inflows in Kenya and therefore the null hypothesis for Exchange rate, GDP and inflation rate was accepted. The negative relationship between GDP, Inflation rate, exchange rate on FDI can be attributed to the length of period under study, 2007 the postelection violence and global financial crisis experienced in 2007-2008 which led to businesses failure. In conclusion Kenya FDI inflows are significantly affected by other factors. It is also perceived by the people of Kenya that FDI is mainly attracted by the availability of market for the goods and services produced by the foreign investors making FDI in
Kenya to be market seeking (69\%) and least important reason to be the political goodwill (34\%) of the country.

Policies in relation to formation of regional treaties between Kenya and neighboring countries with an aim of encouraging foreign investment should be adopted. The government should ensure that security is maintained within and around the country, improvement of infrastructure and political stability is also crucial in attracting and retaining FDIs. In addition the government should increase its fight against corruption in Kenya so as to increase the foreign investor's confidence in investing in our country.

\section{References}

[1] Abala, D. (2014), Foreign Direct Investment and Economic Growth: An Empirical Analysis Of Kenyan Data, DBA Africa Management Review, Vol 4 No 1. Pp. 62-83.

[2] Adina D., Dumitru C., Carol I B. (2012). The Impact of the Recent Global Crisis on Foreign Direct Investment. Evidence from Central and Eastern European Countries. Journal of economics and finance 3 (2012) $1012-1017$.

[3] Arbatli, E. (2011). Economic policies and FDI inflows to emerging market economies, IMF Working Paper.

[4] Ade O. A. Babatunde H. \& Awoniyi M. A (2011).Corruption, Foreign Direct Investment and Growth in Nigeria, \|Journal of Research in International Business Mangement, Vol 1, No9.

[5] Andinuur, J. (2013). Inflation, Foreign Direct Investment and Economic Growth in Ghana, The University of Ghana.

[6] Aremu, J. A. (2005). Foreign Direct Investment and Performance. Paper Delivered At A Workshop On Foreign Investment Policy And Practice Organized By The Nigerian.

[7] Chakraborty, C., and P. Basu (2002). Foreign Direct Investment and Growth in India: A Cointegration Approach. Applied Economics 34: 1061-1073.

[8] Chingarande, A., Karambakuwa, T. Et al (2011). The Impact of Interest Rates on Foreign Direct Investment: A Case Study Of The Zimbabwean Economy (February 2009-June 2011), International Journal of Management Sciences and Business Research, 2012, Vol. 1, No. 5. (ISSN: 2226-8235)

[9] Bouoiyour, J. \& Serge Rey (2005), Exchange Rate Regime, Real Exchange Rate, Trade Flows and Foreign Direct Investments: The Case of Morocco. African Development Bank.

[10] Djokoto, G. (2012). The effect of Investment Promotion on Foreign Direct Investment Inflow into Ghanall. International Business Research, Vol5, No3.

[11] Lipsey, R E (2001) Foreign Direct Investment and the Operations of Multinational Firms: Concepts, History, and Data, Working Paper 8665, National Bureau of Economic Research, Cambridge, Massachusetts, December.

[12] Mahiti, F (2012). Determinants of Foreign Direct Investments (FDIs) In East Africa Countries Of Tanzania And Kenya. (Unpublished MBA Paper). Mzumbe University.

[13] Article on United Nations Conference on Trade and Development (UNCTAD), World Investment Report 1998: Trends and Determinants (New York and Geneva: United Nations). 
[14] Mugenda, O \& Mugenda, A (2003). Research methods; Quantitative \& qualitative approaches. Nairobi; Acts press.

[15] Muthoga, S. K. (2003). The Determinants of Foreign Direct Investment in Kenya (1970- 1999). Published research project, Kenyatta University.

[16] Nabutola, W. (2009). "Urban-Rural Relationship in Land Management and Access to Land- Kenyan Experiences", paper prepared for the 2nd FIG Regional conference, Marrakech.

[17] Kiptui, M. (2007). Does the Exchange Rate Matter for Kenya's Exports? A bounds testing approach. Prepared for presentation at the African Econometric Society 2007 conference, Cape Town, July 4th to 6th 2007.

[18] Kinuthia. (2010). Determinants of Foreign Direct Investment in Kenya: Evidence Annual, African International Business and Management. Leiden: African studies Centre.

[19] Njeru, B. (2013). The Impact of Foreign Direct Investment on Economic Growth in Kenya. Published research project, Nairobi University.

[20] Omankhanlen, A. E. (2011). The Effect Of Exchange Rate And Inflation on Foreign Direct Investment and Its Relationship With Economic Growth In Nigeria, University Of Galati, Journal of economics and applied informatics, years xvii - no1/2011 issn 1584

[21] OECD (2008), Benchmark Definition of Foreign Direct Investment Fourth Edition 2008, OECD publishing. Available at,www.sourceoecd.org/finance/9789264045736

[22] Oude M. K. (2013). The Effect of Exchange Rate Fluctuations on Gross Domestic Product in Kenya. Research Project, University Of Nairobi
[23] Singhania, Monica, \& Akshay G. (2011). Determinants of Foreign Direct Investment in India. Journal of International Trade Law and Policy 10, no. 1 (2011): 64-82.

[24] Society for international Development (2013). The State of East Africa International Report, Nairobi.

[25] The World Bank Group (2016), Foreign Direct Investment Data Inflows.

[26] The World Bank (2012). Kenya Economic Update, Produced By Poverty Reduction and Economic Management Unit Africa Region.

[27] Udoh, E. \& Egwaikhide F. O, (2008). Exchange Rate Volatility, Inflation Uncertainty and Foreign Direct Investment In Nigeria. Botswana, Journal of Economics. 5(7): 14-31.

[28] Udomkerdmongkol M., Gorg H. \& Oliver Morrissey (2006). Foreign Direct Investment and Exchange Rates: A Case Study of US FDI in Emerging Market Countries. University Of Nottingham.

[29] Unctad (2015). World Investment Report, Transnational Corporations, Extractive Industries and Development. http://unctad.org/en/PublicationsLibrary/wir2015_en.pdf

[30] United Nations Conference on Trade and Development (2003). Foreign Direct Investment and Performance Requirements: New Evidence from Selected Countries, Division on Investment, Technology and Enterprise Development Retrieved from Http://Www.Unctad.Org

[31] Yarbrough, B. V. \& Yarbrough, R. M. (2002). The World Economy: Trade and Finance, South- Western College Publishers. 